\title{
Illness Perceptions and Quality of Life in Patients with Diabetes Mellitus Type 2
}

\author{
Dyah A. Perwitasari ${ }^{1}$, Setiyo B. Santosa ${ }^{1}$, Imaniar N. Faridah ${ }^{1}$, Adrian A. Kaptein ${ }^{2}$ \\ ${ }^{1}$ Faculty of Pharmacy, Universitas Ahmad Dahlan, Yogyakarta, Indonesia, ${ }^{2}$ Department of \\ Medical Psychology, Leiden University Medical Centre, Leiden, the Netherlands
}

\begin{abstract}
One of the treatment objectives in patients with type 2 diabetes mellitus (T2DM) is improving their quality of life $(\mathrm{QoL})$. Illness perceptions are major determinant of QOL. This study was aimed to evaluate the QoL of T2DM patients with complications, and to examine the correlation between patients' illness perceptions and QoL. We conducted a cross-sectional study in a private hospital in Yogyakarta, Indonesia from July to September 2015. We recruited adult patients with a diagnosis of T2DM with complications (ICD E.11) that has been diagnosed for at least 3 months. Illness perceptions were assessed with the Brief Illness Perception Questionnaire (BIPQ), and diabetes type 2 specific QoL with the Diabetes Quality of Life for Clinical Trial Questionnaire (DQLCTQ). Data was analyzed using Pearson correlation test. We recruited 51 T2DM patients. Female patients were dominant and most of the subjects experienced T2DM more than 5 years. The BIPQ scores indicated that patients had positive perceptions about T2DM and the treatment in all domains, except for coherence. Scores on the DQLCTQ showed that T2DM patients' QoL is good, except for the self satisfaction and treatment effect. Statistically significant positive correlations were observed between BIPQ dimensions of personal control, treatment control and coherence and QoL domains $(\mathrm{p}<0.01)$. Moreover, the strong negative correlation were observed between consequences, concern and emotional response and QoL domains $(p<0.01)$. However, 92\% correlations are weak. Illness perceptions are correlated with T2DM patients' QoL. Interventions aimed to get more adaptive illness perceptions may impact positively on QoL.
\end{abstract}

Keywords: BIPQ, DQLCTQ, illness perceptions, Indonesia, QoL, T2DM

\section{Persepsi terhadap Penyakit dan Kualitas Hidup Pasien Diabetes Melitus Tipe 2}

\begin{abstract}
Abstrak
Salah satu tujuan terapi DM tipe 2 adalah memperbaiki kualitas hidup pasien. Persepsi terhadap penyakit merupakan penentu utama dari kualitas hidup. Tujuan penelitian ini adalah untuk mengevaluasi kualitas hidup pasien pada pasien DM tipe 2 dengan komplikasi serta mengetahui hubungan antara persepsi pasien dan kualitas hidup. Rancangan penelitian ini adalah potong lintang yang dilakukan di rumah sakit swasta di Yogyakarta. Subyek yang berpartisipasi dalam penelitian ini adalah pasien DM tipe 2 dewasa dengan komplikasi yang terdiagnosa minimal 3 bulan sebelum penelitian ini dimulai (ICD E11). Kualitas hidup diukur dengan Diabetes Quality of Life for Clinical Trial Questionnaire (DQLCTQ) dan persepsi pasien diukur dengan Brief Illness Perception Questionnaire (BIPQ). Sejumlah 51 pasien DM tipe 2 dengan komplikasi turut berpartisipasi dalam penelitian ini dari bulan Juli sampai September 2015. Mayoritas subjek adalah wanita dan sebagian besar pasien mengalami DM tipe 2 lebih dari 5 tahun. Skor domain BIPQ memperlihatkan bahwa pasien DM tipe 2 mempunyai persepsi yang positif terhadap penyakit dan pengobatannya pada semua domain kecuali koherensi. Skor domain DQLCTQ memperlihatkan bahwa pasien mempunyai kualitas hidup yang baik, kecuali domain kepuasan pribadi dan efek terapi (berturut-turut 55,6 dan 44,3). Korelasi kuat yang positif terlihat pada domain persepsi kontrol diri, kontrol terapi dan koherensi dengan semua domain kualitas hidup $(\mathrm{p}<0,01)$. Korelasi kuat yang negatif terlihat pada domain konsekuensi, kekhawatiran dan respon emosi dengan kualitas hidup $(\mathrm{p}<0,01)$. Sejumlah 92\% korelasi BIPQ dan DQLCTQ adalah lemah. Persepsi pasien dan komplikasi dapat memengaruhi kualitas hidup pasien DM tipe 2. Intervensi yang bersifat memperbaiki persepsi pasien akan berdampak positif terhadap kualitas hidup.
\end{abstract}

Kata kunci: BIPQ, DM tipe 2, DQLCTQ, Indonesia, kualitas hidup, persepsi

Correspondence: Dr. Dyah A. Perwitasari, M.Si., Ph.D., Apt., Faculty of Pharmacy, Universitas Ahmad Dahlan, Yogyakarta, Yogyakarta Province, 55166, Indonesia, email: da_perwitasari@uad.ac.id

Received: $2^{\text {nd }}$ December 2016, Accepted: $3^{\text {rd }}$ July 2017, Published: $1^{\text {st }}$ September 2017 


\section{Introduction}

The prevalence of diabetes mellitus (DM) in Indonesia is $6.2 \%$ in 2015 , and it is predicted to affect 21.3 million people in 2030 when the population in Indonesia will be 345 million people. ${ }^{1,2} \mathrm{DM}$ is one of the chronic diseases which has a major impact on the quality of life (QoL) of persons afflicted. ${ }^{3}$ QoL is conceptualized as individuals' perceptions of their position in life in the context of the culture and value systems in which they live and in relation to their goals, expectations, standards and concerns. ${ }^{4}$ Several determinants may affect QoL, such as age, sex, type of medication, complications, illness perceptions, coping and social support. ${ }^{3,5}$ A previous study in Indonesia in one private hospital found that the diferent types of treatment may affect patients' adherence and QoL. In another study, patient adherence to the medication prescribed was associated with QoL. ${ }^{6,7}$

Diabetes may lead to complications, like micro and macrovascular complications. Macrovascular complications are due to the damage of large blood vessels, such as myocardial infarction, stroke and peripheral arterial disease. Microvascular complications are due to the damage of small blood vessels, such as retinopathy, neuropathy and nephropathy. ${ }^{8,9}$ A previous study showed that peripheral sensory neuropathy, coronary artery disease and peripheral vascular disease are associated with lower score of some QoL domains. ${ }^{10}$ A study conducted in South Korea, showed that patients with hypertension and diabetes had lower scores on EQ-5D, a measure of functional status, than patients with hypertension only and diabetes only. The differences in EQ-5D scores among the complicated and non-complicated patients were significant $(\mathrm{p}<0.05){ }^{11}$

The Common Sense Model (CSM) is a multi level framework which depicts the process of self-regulation of health and disease. The CSM views the patients in the socio-cultural context who according to their beliefs of disease and treatment may adjust their life to get better treatment outcome. ${ }^{12,13}$ Some of the patients' characteristics may influence their illness perceptions, such as age and education. Moreover, patients' illness perceptions could associate with glycemic control. Psychological interventions aimed at changing patients' illness perceptions may lead to a better therapeutic outcome. ${ }^{13}$

A study made the similar conclusion that DM had negative influence or may deteriorate patients' QoL. Associaton between patients' perception and QoL in people with diabetes mellitus in Indonesia has not been explored yet. Our previous study found that the type of treatment may influence patients' adherence and QoL. ${ }^{7}$ Thus, we need to understand the association between perceptions and Indonesian diabetes mellitus type 2 (T2DM) patients' QoL. The different level of perceptions which could be caused by the different quality of health provider, especially in educating the chronic diseases' patients during the treatment, may influence patients' QoL. This study was conducted in the hospital because we need to recruit T2DM patients who were treated according to the particular guidelines and particular service of health provider. This study was aimed to evaluate illness perceptions (IPs) in patients with T2DM and to understand the associations between IPs and QoL.

\section{Methods}

We conducted a cross-sectional study in a private hospital in Yogyakarta, Indonesia. The consideration of using private hospital in our study due to the results of our previous study that patients in private hospital need more aspect to be considered to increase pharmaceutical care. ${ }^{7}$ We recruited adult 
outpatients with diagnosis of T2DM with complications who visited internist polyclinic from July 2015 until September 2015. We chose this period due to the study permition from the hospital. Complications were defined as macrovascular and microvascular according to the ICD E. ${ }^{11}$ The diagnosis of T2DM patients was found in the medical record. Subjects were recruited if they have been diagnosed more than three months ago. We decided not to recruit newly diagnosed patients to avoid the coping process of the patients as new T2DM patients with the perspectives of treatment and lifestyle which could influence the QoL. ${ }^{14}$ We excluded pregnant women and lactating women in order to minimize other metabolism factors which can affect the patients' quality of life. Moreover, pregnant women may experience distressful period which could decrease the QoL. ${ }^{15}$

The patients' IPs and QoL were measured by Brief Illness Perception Questionnaire (BIPQ) and Diabetes Quality of Life for Clinical Trial Questionnaire (DQLCTQ), respectively. Patients filled in the questionnaires after the informed consent

Table 1 Sociodemographic of Subjects

\begin{tabular}{lc}
\hline Characteristic & n (\%) \\
\hline Gender & $23(45.1)$ \\
Male & $28(54.9)$ \\
Female & \\
Education & $36(70.6)$ \\
Up to senior high school & $15(29.4)$ \\
More than senior high school & \\
Occupation & $22(28.4)$ \\
Jobless & $29(21.6)$ \\
Occupied & $49 \pm 20.7$ \\
Age (age \pm mean) & $6.5 \pm 5.9$ \\
Duration of T2DM (years) & \\
Complications & $3(5.9)$ \\
Hyperlipidemia & $40(78.4)$ \\
Hypertension & $4(7.8)$ \\
Heart attack & $8(15.7)$ \\
Neuropathy & $1(2)$ \\
Nephropathy & $2(3.9)$ \\
Stroke &
\end{tabular}

procedure. The BIPQ is available in Bahasa Indonesia. This questionnaire also widely used in the psychological area to understand patients' behaviour in particular chronic disease, such as heart attack, cancer, diabetes and rheumatoid arthritis [www.uib.no/ipq]. The BIPQ assesses eight dimensions, i.e., consequences, timeline, personal control, treatment control, identity, concern, coherence and emotional response. The higher score of BIPQ domains, the more negative perception of patients (question number 1, 2, 5, 6, 8). On the other dimensions (i.e., personal control, treatment control and coherence) the higher the score, the more positive the perceptions of the patients are (number 3, 4, and 7). ${ }^{16}$ The DQLCTQ is a disease specific instrument of DM quality of life and includes 8 domains: physical function (6 questions), energy (2 questions), health distress (6 questions), mental health (2 questions), satisfaction (15 questions), treatment satisfaction (3 questions), treatment effect ( 9 questions), and frequency of symptoms (7 questions). This questionnaire is widely used in Indonesia, even in the clinical trial study to observe QoL as the outcome or in the observational study. ${ }^{17}$ Demographic data of the patients were collected from the questionnaire.

Correlation between IPs and QoL were calculated using Pearson correlation test due to the normality distribution of data, however, Spearman correlation test was performed for non-parametric data. Our study results were compared to other previous study results to enrich the discussion. This study has been approved by Ethics Committee of Universitas Ahmad Dahlan, No. 011504039.

\section{Results}

We recruited 51 T2DM patients with complications. Table 1 presents patient characteristics; most of the patients were female. The mean age of patients was 49 
Table 2 B-IPQ Scores of T2DM Patients

\begin{tabular}{lc}
\hline Dimensions & T2DM with Complications $(\mathbf{n}=\mathbf{5 1})$ \\
\hline Consequences & $6.27 \pm 2.25$ \\
Timeline & $5.33 \pm 2.91$ \\
Personal control & $8.90 \pm 1.78$ \\
Treatment control & $8.88 \pm 1.33$ \\
Identity & $4.96 \pm 2.00$ \\
Concern & $4.90 \pm 2.54$ \\
Coherence & $7.86 \pm 1.75$ \\
Emotional response & $5.96 \pm 2.57$ \\
\hline
\end{tabular}

years ( $\mathrm{SD}=20.7$ years) and the mean of T2DM duration was 6.5 years $(\mathrm{SD}=5.9$ years). Most of the patients had hypertension (78.4\%) as the complication. Table 2 presents the BIPQ in our study. The positive perceptions are shown in all domains of BIPQ, except for coherence (7.86 \pm 1.75$)$. In general, there are no influence of demographic factors to QoL domains, except for the patients' sex and treatment satisfaction, geriatric patients and health problems, high blood pressure and symptoms frequency-health problem, working status and physical function (data were not shown).

Table 3 presents the DQLCTQ domains' differences between T2DM patients with and without complication. ${ }^{7}$ The significant differences are shown in all domains except for physical function and mental health $(p<0.01)$. In general, the scores of quality of life domains in the 'without complication' group are higher than the scores in the "with complication' group, except for physical function and mental health. We analyzed the QoL domain differences among the types of complications. However, there were no significant differences among the types of complications (data were not shown).

Table 4 presents the associations between patients' illness perceptions and their quality of life. Some domains of BIPQ are significantly associated with quality of life domains, such as consequence, concern, coherence and emotional response. The strong correlations are seen on consequences-physical function, emotional response-health problem, concernenergy, concern-mental health. However the weak correlations are seen on most domains of BIPQ and DQLCTQ.

Some of the BIPQ domains have positive correlation with the QoL domains like personal control, treatment control and coherence with frequency of symptoms, satisfaction, vitality/energy, mental health and treatment effect. Negative correlations were found in identity and concern with physical function,

Table 3 QoL Domains Scores [DQLCTQ] in Patients Without and With Complications

\begin{tabular}{lccc}
\hline Domains & $\begin{array}{c}\text { Without Complication } \\
(\text { Mean } \pm \mathbf{S D})^{\mathbf{7}}, \mathbf{n}=\mathbf{8 8}\end{array}$ & $\begin{array}{c}\text { With Complication } \\
\text { (Mean } \pm \text { SD), } \mathbf{n = 5 1}\end{array}$ & p-value \\
\hline Physical function & $76.5 \pm 25.47$ & $68.5 \pm 25.12$ & 0.204 \\
Health problem & $95.0 \pm 7.38$ & $85.1 \pm 10.05$ & $<0.01^{*}$ \\
Self satisfaction & $82.3 \pm 8.75$ & $55.6 \pm 8.19$ & $<0.01^{*}$ \\
Energy & $80.8 \pm 18.53$ & $62.0 \pm 14.09$ & $<0.01^{*}$ \\
Mental health & $76.9 \pm 9.17$ & $77.0 \pm 10.82$ & 0.968 \\
Treatment effect & $65.9 \pm 18.42$ & $43.4 \pm 9.23$ & $<0.01^{*}$ \\
Frequency of symptoms & $81.3 \pm 13.46$ & $72.5 \pm 14.41$ & $<0.01^{*}$ \\
Treatment satisfaction & $94.0 \pm 11.03$ & $79.9 \pm 9.18$ & $<0.01^{*}$ \\
\hline *= significant & & &
\end{tabular}


treatment flexibility, frequency of symptoms, vitality, health distress, mental health and satisfaction.

\section{Discussion}

Our study found some of BIPQ domains have positive beliefs, such as personal control, treatment control and coherence. The negative perceptions were seen on the domains of consequence, timeline, identity, concern and emotional response.

Regarding to the score of QoL domains in our study, complication affected the patients' QoL. This finding is also in accordance with the previous studies which showed that the end-stage complications gave high burden to the QoL. ${ }^{18,19}$ Hypertension itself did not influence to all QoL domain, even though the T2DM patients with complications had worse QoL than T2DM patients without complications. However, we found that T2DM patients with high blood pressure experienced worsening of symptoms frequency and health problem. These results are similar to previous study in American among the American Indian. ${ }^{20}$ Other study also presented that the mild complications in DM patients may result the significant impact to the patients QoL. This study suggested giving early treatment and diagnosis to the patients. ${ }^{10}$ One of the DM treatment goals is to prevent the

Table 4 Correlations (Pearson) Between B-IPQ and DQLCTQ

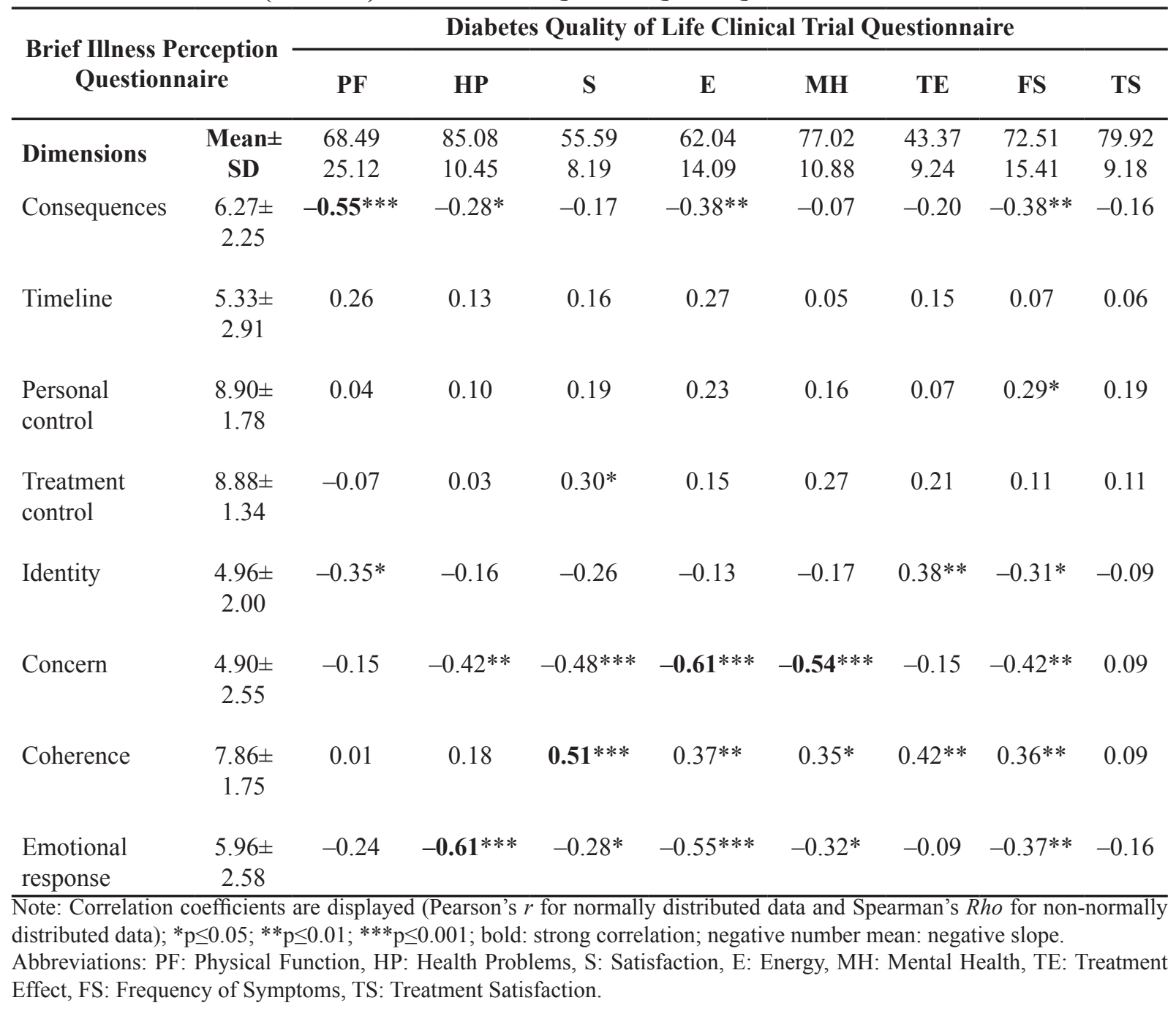


complications, however previous study found that the treatment policies which purposed to reduce the complication risk cannot improve patients' quality of life. ${ }^{8}$

Our study findings are in line with the previous study that the negative perception was associated with lower score of quality of life. ${ }^{18}$ Consequence domain had negative correlations with physical function, vitality/ energy, health distress and frequency of symptoms. Patients felt that the disease significantly influence their physical function, energy health distress and also associated with the increase of disease symptoms. Previous studies also reported that belief in serious consequences were negatively associated with health distress ${ }^{21,22}$ and emotional function. ${ }^{23,24}$ Timeline was positively weak correlated with all domains of QoL. Contradictively, the previous study found that length of disease scores are associated with poor emotional health ${ }^{23,24}$ and health distress. ${ }^{21,25}$ Furthermore, perceptions of shorter duration was related to greater diabetes self-management. . $^{21,26}$

Our findings show that perceptions of personal control are positively related to a frequency of symptoms. This finding is in line with the previous study which reported that higher personal control beliefs associated with better metabolic control. ${ }^{27}$ Moreover, lower personal control scores are associated with poor emotional health in diabetes ${ }^{23,24}$ and greater diabetes-related distress. ${ }^{21}$ Patients who perceived that they had the ability to control their diabetes, reported that they had more physical activities. ${ }^{28-30}$ Treatment control is the extent to which the patients believe that the treatment may control their illness..$^{27,31,32}$ Our finding showed that more positive perceptions of treatment control is related to a better role limitation due to emotional problems and satisfaction. Furthermore, greater treatment effectiveness were associated with greater diabetes self-management ${ }^{26}$ and deterioration of diabetes-related distress. ${ }^{21}$
Identity is the particular label the patients used to describe what symptoms their perceive as part of the illness. ${ }^{32}$ Our finding indicated that more physical complaints due to patients with T2DM with complications is related to a lower physical function, role limitation due to physical health treatment, treatment flexibility and frequency of symptoms. However, previous study concluded that identity negatively correlated with physical component summary and mental component summary in SF-12 performance. ${ }^{33}$ In addition, high identity scores are associated with lack of emotional distress ${ }^{24}$ and greater diabetes-related distress. ${ }^{22}$ Concern is the emotional representation of the level of worry of the illness generates. ${ }^{31,32,34}$ Our study found similar result to previous studies, it was suggested that more concerns about patients with T2DM with complications are related to a poorer emotional function/mental health. ${ }^{19,24}$ This could be caused by more symptoms experienced and more medication that should be consumed by the patients. Coherence is the overall comprehension of illness factor. ${ }^{31,32,34}$ Previous study reported that there was a positive relationship between illness coherence and quality of life. ${ }^{35}$ In addition, Paddison et al. (2010) also concluded that low illness coherence scores are associated with greater diabetes-related distress. ${ }^{22}$ Emotional response is assessment of the emotional responses generated by the illness. ${ }^{32}$ As previous reports, we also found that high emotional response scores are related to health distress ${ }^{21}$ and emotional function (mental health). ${ }^{24}$

Strong correlations among consequencesphysical function, emotional response-health problem, concern-energy, concern-mental health show that over the CSM context of T2DM patients, some psychiatric parameters may influence the treatment outcome. The perceptions about consequences, emotional response and concern about the disease, 
which they think will be getting worse, may change the physical function, vitality and mental health. Some clinical characteristics, such as high bold pressure also had a role in influencing patients' QoL. Previous studies in the context of the CSM showed that patients' perceptions affect patients' illness distress which is related to emotional outcomes. Patients' perception about diabetes symptoms and treatment were associated with greater diabetes distress in a study in New Zealand patients $(n=615)$, where distress was assessed with Problems Areas in Diabetes (PAID). ${ }^{22}$ A systematic review and meta analysis which included nine cross-sectional and four randomized control trial studies regarding illness perceptions in people with diabetes showed that illness perceptions had a small but significant association with glycaemic control; however, the direction of the associations remained unclear. ${ }^{36}$ DM patients' life may change because of the consequences of the chronic disease. They experience symptoms related to hypoglycemia or hyperglycemia, the change of lifestyle including diet, exercises, sleeping pattern and daily activities. They also have to adhere to the routine physician and laboratory evaluation. ${ }^{37}$ These situation may change patients' perception about their life and furthermore may impact the QoL. ${ }^{38}$ Previous study suggested that a positive self-perception played an important role in self management, especially in increasing the patients' compliance to treatment. ${ }^{39}$

The limitation of our study is regarding the outpatients of T2DM with complications who was recruited. The wide gap of number among of listed complications, it is not possible to controls the displayed results. Because of the cross-sectional design, conclusions about causality cannot be drawn in this study. However, the findings in present study confirmed that presence of complications have a significant negative impact on QoL among the patients with T2DM. These results also cannot be generalized into Indonesian T2DM patients, due to differences of culture in every island and service quality of each health providers. This finding should be considered in the design of intervention and monitoring programmes for patients with T2DM with complications, in order to planning and implementation of "patient oriented" that involve assisting with the needs and improving the QOL of individuals.

\section{Conclusion}

According to present finding, we suggest patients' perceptions may affect patients' QoL. Some of perceptions domains, such as consequences, emotional health and concern are correlated to physical functions of T2DM patients. The high blood pressure could worsen T2DM patients QoL.

\section{Acknowledgements}

The authors thank the hospital staffs who helped the researcher in patient recruitment and collecting the data.

\section{Funding}

The study was not funded by any source of grants.

\section{Conflict of Interest}

The authors have no conflict of interest.

\section{References}

1. Department of Health of the Republic of Indonesia. The prevalence of diabetes melitus in Indonesia reach 21.3 million people in 2030 [Accessed on: 11 October 2016]. Available at: http://www.depkes. go.id/article/view/414/tahun-2030-preva 
lensi-diabetes-melitus-di-indonesia-men capai-213-juta-orang.html

2. Department of Health of the Republic of Indonesia. National health survey [Accessed on: 11 October 2016]. Available at: http:// www.depkes.go.id/resources/download/ general/Hasil\%20Riskesdas\%202013.pdf

3. Megari K. Quality of life in chronic disease patients. Health Psychol Res. 2013;1(3): e27. doi: 10.4081/hpr.2013.e27

4. World Health Organization. Program on mental health, 1997 [Accessed on: 11 October 2016]. Avaliable at: http://www. who.int/mental_health/media/68.pdf

5. AlHayek AA, Robert AA, AlSaeed A, Alzaid AA, AlSabaan FS. Factors associated with health-related quality of life among Saudi patients with type 2 diabetes mellitus: A cross-sectional survey. Diabetes Metab J. 2014;38(3):220-9. doi: 10.4093/dmj.2014.38.3.220

6. Alfian SD, Sukandar H, Lestari K, Abdulah R. Medication adherence contributes to an improved quality of life in type 2 diabetes mellitus patients: A cross-sectional study. Diabetes Ther 2016;7(4):755-64. doi: 10. 1007/s13300-016-0203-x

7. Perwitasari DA, Adikusuma W, Rifkifani S, Supadmi W, Kaptein AA. Quality of life and adherence of diabetic patients in different treatment regimens. Indones $\mathrm{J}$ Clin Pharm. 2014;3(4):107-13. doi: 10. 15416/ijcp.2014.3.4.107

8. UKPDS 37. Quality oflife in type 2 diabetic patients is affected by complications but not by intensive policies to improve blood glucose or blood pressure control(UKPDS 37). Diabetes Care. 1999;22(7):1125-36.

9. World Health Organization. About diabetes [Accessed on: 11 August 2016]. Available at: http://www.who.int/diabetes/action online/basics/en/index3.html.

10. Lloyd A, Sawyer W, Hopkinson P. Impact of long-term complications on quality of life in patients with type 2 diabetes not using insulin. Value Health. 2001;4(5): 392-400. doi: 10.1046/j.1524-4733.2001. 45029.x

11. Chin YR, Lee IS, Lee HY. Effects of hypertension, diabetes, and/or cardiovascular disease on health-related quality of life in elderly Korean individuals: A population-based cross-sectional survey. Asian Nurs Res. 2014; 8(4):267-73. doi: 10.1016/j.anr.2014.10. 002

12. McAndrew LM, Musumeci-Szabó TJ, Mora PA, Vileikyte L, Burns E, Halm EA, et al. Using the common sense model to design interventions for the prevention and management of chronic illness threats: From description to process. Br J Health Psychol. 2008;13(Pt 2):195-204. doi: 10.1348/135910708X295604.

13. Gonzalez JS, Tanenbaum ML, Commissariat PV. Psychosocial factors in medication adherence and diabetes self-management: Implications for research and practice. Am Psychol. 2016;71(7):539-51. doi: 10. 1037/a0040388

14. Farmer A, Hardeman W, Hughes D, Prevost AT, Kim Y, Craven A, et al. An explanatory randomised controlled trial of a nurse-led, consultation-based intervention to support patients with adherence to taking glucose lowering medication for type 2 diabetes. BMC Fam Pract. 2012;13:30. doi: 10.1186/1471-22 96-13-30

15. Bahadoran P, Mohamadirizi S. Relationship between physical activity and quality of life in pregnant women. Iran J Nurs Midwifery Res. 2015;20(2):282-6.

16. Universitas Bergensis. The illness perception questionnaire [Accessed on 11 June 2016]. Available at: http://www.uib.no/ipq/

17. Perwitasari DA, Urbayatun S. Treatment adherence and quality of life in diabetes mellitus patients in Indonesia. Sage Open. 2016;6(2):1-7. doi: 10.1177/2158244016 643748 
18. Huang ES, Brown SE, Ewigman BG, Foley EC, MeltzerDO. Patient perceptions of quality of life with diabetes-related complications and treatments. Diabetes Care. 2007;30(10):2478-83. doi: 10.2337 /dc07-0499.

19. Quah JH, Luo N, Ng WY, How CH, Tay EG. Health-related quality of life is associated with diabetic complications, but not with short-term diabetic control in primary care. Ann Acad Med Singapore. 2011;40(6):276-86.

20. JiangL,BealsJ, WhitesellNR, Roubideaux Y, Manson SM. Health-related quality of life and help seeking among American Indians with diabetes and hypertension. Qual Life Res. 2009;18(6):709-18. doi: 10.1007/s11136-009-9495-X

21. Bridges HA, Smith MA. Mediation by illness perceptions of the association between the doctor-patient relationship and diabetes-related distress. J Health Psychol. 2016;21(9):1956-65. doi: 10.11 77/1359105315569094

22. Paddison CAM, Alpass FM, Stephens CV. Using the common sense model of illness self-regulation to understand diabetes-related distress: the importance of being able to 'make sense' of diabetes. NZ J Psychol. 2010;39(1):45-50.

23. Hudson JL, Bundy C, Coventry PA, Dickens C. Exploring the relationship between cognitive illness representations and poor emotional health and their combined association with diabetes selfcare: A systematic review with metaanalysis. J Psychosom Res. 2014;76(4): 265-74. doi: 10.1016/j.jpsychores.2014. 02.004

24. Wu H, Zhao X, Fritzsche K, Salm F, Leonhart R, Jing W, et al. Negative illness perceptions associated with low mental and physical health status in general hospital outpatients in China. Psychol Health Med. 2014;19(3):273-85. doi: 10.
1080/13548506.2013.802358.

25. Miftari S, Melonashi E. The impact of stress in quality of life in patients with diabetes. Eur J Psychol Res. 2015;2(1): 73-9.

26. Ponzo MG, Gucciardi E, Weiland M, Masi R, Lee R, Grace SL. Gender, ethnocultural, and psychosocial barriers to diabetes self-management in Italian women and men with type 2 diabetes. Behav Med. 2006;31(4):153-60. doi: 10. 3200/BMED.31.4.153-160

27. BroadbentE, PetrieKJ, Main J, Weinman J. The brief illness perception questionnaire. J Psychosom Res. 2006;60(6):631-7. doi: 10.1016/j.jpsychores.2005.10.020

28. Gherman A, Schnur J, Montgomery G, Sassu R, Veresiu I, David D. How are adherent people more likely to think? A meta-analysis of health beliefs and diabetes self-care. Diabetes Educ. 2011; 37 (3):392-408. doi: 10.1177/014572171 1403012

29. Lawson VL, Bundy C, Harvey JN. The development of personal models of diabetes in the first 2 years after diagnosis: A prospective longitudinal study. Diabet Med. 2008;25(4):482-90. doi: 10.1111/j.1464-5491.2008.02394.x

30. van Puffelen AL, Heijmans MJ, Rijken M, Rutten GE, Nijpels G, Schellevis FG. Illness perceptions and self-care behaviours in the first years of living with type 2 diabetes: Does the presence of complications matter?. Psychol Health. 2015;30(11):1274-87. doi: 10.1080/ 088 70446.2015.1045511.

31. Moss-Morris R, Weinman J, Petrie KJ, Horne R, Cameron L, Buick D. The revised illness perception questionnaire (IPQ-R). Psychol Health. 2002;17(1):16. doi: 10.1080/08870440290001494

32. Voigt A, Madrid E, Pacheco-Huergo V, Rastello A, Castro D, Navarro-Brito I, et al. Association of glycaemia with perceived threat of illness in patients 
with type 2 diabetes. Prim Care Diabetes 2015;9(6):426-31. doi: 10.1016/j.pcd.20 15.03 .001

33. Mc Sharry J, Moss-Morris R, Kendrick T. Illness perceptions and glycaemic control in diabetes: A systematic review with meta-analysis. Diabet Med. 2011;28 (11):1300-10. doi: 10.1111/j.1464-5491. 2011.03298.x.

34. Leventhal H, Neerenz D, Steele D. llness representations and coping with health threats, in: Baum A, Taylor SE, Singer JE. Handbook of Psychology and Health. Hillsade, New Jersey: Lawrence Erlbaum Associates; 1984:219-52.

35. Skinner TC, Carey ME, Cradock S, Daly H, Davies MJ, Doherty Y, et al. Diabetes education and self-management for ongoing and newly diagnosed (DESMOND): Process modelling of pilot study. Patient Educ Couns. 2006;64(13):369-77. doi: 10.1016/j.pec.2006.04.007 36. McSharry J, Moss-Morris R, Kendrick T.
Illness perceptions and glycaemic control in diabetes: A systematic review with meta-analysis. Diabet Med. 2011;28(11): 1300-10. doi: 10.1111/j.1464-5491.2011. 03298.x.

37. Fisher L, Glasgow RE, Strycker LA. The relationship between diabetes distress and clinical depression with glycemic control among patients with type 2 diabetes. Diabetes Care. 2010;33(5):1034-6. doi: 10. 2337/dc09-2175

38. Huang ES, Brown SE, Ewigman BG, Foley EC, Meltzer DO. Patient perceptions of quality of life with diabetes-related complications and treatments. Diabetes Care. 2007;30(10):2478-83. doi: 10.2337 /dc07-0499

39. Rostami S, Parsa-Yekta Z, NajafiGhezeljeh T, Vanaki Z, Zarea K. Selfperception in Iranian adolescents with diabetes: A qualitative study. J Diabetes Metab Disord. 2015;14:36. doi: 10.1186/ s40200-015-0163-0 